\title{
A importância da ultrassonografia transabdominal (FLASH) no diagnóstico de deslocamento de cólon à direita: relato de caso
}

Maria Augusta Berlingieri, Paulo Ari Leiria, Julietti Beatriz Vieira, Caue Natam de Souza, Alisson Romano da Silva

EQÜIVET-Hospital Veterinário, Indaiatuba, SP, Brasil

*Autor correspondente

e-mail: gutaberlingieri1@hotmail.com

\section{Resumo}

A ultrassonografia transabdominal em equinos com cólica tem sido utilizada rotineiramente em muitos hospitais veterinários. A técnica ultrassonográfica FLASH é uma adequação da técnica FAST (específica para pacientes de UTI nos traumas toracoabdominais em humanos e pequenos animais), que é utilizada para identificação e avaliação dos órgãos abdominais dos equinos. É uma técnica de varredura rápida e valiosa quanto à localização, aparência e conteúdo dos órgãos abdominais, e fornece informações quanto à determinação de diagnóstico, recomendação cirúrgica ou manejo clínico, e além disso permite monitoramento da resposta terapêutica. No abdômen equino normal, a vasculatura colônica ascendente cursa ao longo do aspecto medial do cólon e pode não ser visível durante o exame ultrassonográfico transabdominal. A proposta do presente relato é de firmar que a visualização da vascularização colônica ascendente do lado direito do abdômen durante uma ultrassonografia transabdominal pode sugerir deslocamento de cólon ascendente à direita ou vólvulo colônico de $180^{\circ}$. Um equino, fêmea, Sela Holandesa, 5 anos de idade, castanha, foi encaminhada ao EQÜIVET-Hospital Veterinário com queixa de desconforto abdominal irresponsivo à terapia realizada na propriedade. Durante o atendimento hospitalar, os parâmetros clínicos foram FC : $36 \mathrm{bpm}, \mathrm{FR}: 16 \mathrm{mrm}$, TPC : 2", mucosas róseas, temperatura retal de 37,5 ำ. Os valores de hematócrito de 37\% e proteína total de 6g/dl; lactato venoso de 4,7 mmol/L. Foram realizadas sondagem nasogástrica e lavagem do estômago. A palpação transretal evidenciou presença de distensão gasosa exacerbada. A ultrassonografia transabdominal foi realizada utilizando um aparelho GE (Vivid e) com um transdutor convexo de frequência de 2,5-5 Mhz. A varredura do abdômen foi realizada de caudal para cranial e em sentido dorso ventral em ambos lados. 0 cólon foi identificado pelas saculações características entre $12^{\circ}$ e $17^{\circ}$ espaços intercostais direito, e a vascularização colônica ascendente foi definida por duas ou mais estruturas hipoecóicas circulares diretamente adjacentes à parede do cólon, aproximadamente 
no nível da junção costocondral, com a probe orientada transversamente à coluna vertebral. Devido aos achados descritos durante a avaliação, o animal foi encaminhado à celiotomia exploratória. No período transcirúrgico, após a inspeção da cavidade abdominal, foi encontrado deslocamento de cólon maior à direita (anti-horário). Após a remoção do gás através de aspiração, o deslocamento foi corrigido, sendo em seguida realizada enterotomia para remoção do conteúdo e enterorrafia. Após inspeção da cavidade abdominal, as alças intestinais foram anatomicamente reposicionadas e efetuada rafia da parede de forma convencional. 0 animal foi monitorado 24 horas durante a permanência no hospital e recebeu alta médica 15 dias após o procedimento cirúrgico. Em estudos retrospectivos de equinos submetidos à celiotomia exploratória por cólica, a visualização ultrassonográfica da vasculatura colônica no lado direito do abdômen parece ser um achado altamente sensível e específico para deslocamento de cólon à direita. Por tratar-se de um método não invasivo e de fácil execução, a ultrassonografia FLASH pode ser incorporada como auxiliar na avaliação do abdômen agudo, principalmente devido à acurácia dos achados nos deslocamentos de cólon à direita.

Palavras-chave: Ultrassonografia. Equino. Deslocamento. 